\title{
WINNOWING DERIVATIVE SUITS THROUGH ATTORNEYS FEES
}

\author{
A. F. CONARD* \\ I \\ INTRODUCTION
}

This article is written on the suppositions that the viability of shareholder derivative suits is a vital support to the U.S. free enterprise economy, that derivative suits are the major policemen of managerial integrity, and that without derivative suits, passive equity investment could not flourish. ${ }^{1}$ Other countries have other disciplinary devices, ${ }^{2}$ but the derivative suit is the preeminent disciplinary device in the United States.

The article is written on some further suppositions of a more negative character-that a significant proportion of derivative suits are worse than useless, ${ }^{3}$ that

Copyright $(\mathcal{C} 1984$ by Law and Contemporary Problems

* Henry M. Butzel Professor of Law Emeritus, University of Michigan Law School. The author was assisted in research by Vicky Bush-Joseph and Michael Ziffrig and received a helpful critique from Professor Stuart Cohn.

1. For classic indorsements of derivative suits, see the comments of Justice Frankfurter in Cohen $\mathrm{v}$ Beneficial Indus. Loan Corp., 337 U.S. 541, 548 (1949) and of Judge Rifkind in Brendle v. Smith, 46 F. Supp. 522, 525-26 (S.D.N.Y. 1942); Ballantine, Abuses of Shareholders Derivative Suits: How Far is Califomia's New "Security for Expenses" Act Sound Regulation?', 37 Calif. L. REv. 399 (1949); Carson, Cument Phases of Derivative Actions Against Directors, 40 MiCH. L. REv. 1125 (1942); Dykstra, The Revival of the Derivative Suit, 116 U. PA. L. REV. 74 (1967).

2. See generally Grossfeld, Management and Control of Marketable Share Companies, in 13 InTERNATIONAL ENCYCLOPEDIA OF COMPARATIVE LAW ch. 4 (1973). In Germany, publicly held corporations are required to have supervisory councils, in which executives cannot be members, which negotiate all transactions between the corporation and executives. German Stock Corporation Law $\S \S 105,112$ (R. Mueller \& E.G. Galbraith trans. 2d ed. 1976).

In France, public companies must have independent auditors whose duties include ascertaining that the shareholders receive equal treatment and reporting to the state prosecutor any violations of law that come to their attention. French Law on Commercial Companies, art. 228, para. 3 \& art. 233, para. 2 (1971); Tunc, A French Lawyer Looks at American Corporation Law and Securities Regulation, 130 U. PA. L. REV. 757, 760-61 (1982).

In Great Britain, where the shareholder's right to maintain a derivative suit is very limited, a shareholder may petition the court to cause an action to be brought in the company's name. Companies Act, $1980 \mathrm{ch} .22, \S 75(4)(\mathrm{c})$

In Canada, company laws have been amended within the past decade to forsake the traditional British restrictions on derivative suits and permit them to be brought along lines similar to those authorized in the United States. See Canadian Business Corporations Act, ch. 33, \$\$ 232, 233, 1974-76 Can. Stat. 709, 88687 (1975). Similar statutes have been enacted in several provinces. See Hansen, Annual Survey of Canadian Law-Corporation Law, 10 OTTAWA L. REV. 617, 674-87 (1978).

In Australia, a shareholder may petition the court for an order regulating affairs of the company. [Australian] Companies Act, 1981, \$ 320, AustL. ACTs P. no. 89 (1981).

3. As professors John Coffee and Donald Schwartz observe, recent developments restricting derivative suits have not been preceded by any systematic demonstrations of their deleterious consequences. Coffee $\&$ Schwartz, The Survival of the Derivative Sut: An Evaluation and a Proposal for Legislative Reform, 81 CoLUM. L. REV. 261, 262 (1981). Nevertheless, an impression that a number of opportunistic suits were being filed probably arose in the 1970's from the flurry of actions based on illegal foreign payments and political 
the dynamics of derivative suits tend to encourage useless as well as useful suits, ${ }^{4}$ and that unless the useless suits can be selectively controlled, judges or legislators will suppress the good with the bad. ${ }^{5}$

These propositions are debatable, but this article does not debate them. Rather, it addresses readers who consider them sufficiently plausible to justify exploring means of winnowing out potential suits that would be useless while garnering those that would contribute to the corporate economy.

Policymakers cannot hope to winnow out at their inception all the suits that will eventually fail. The suits that they can reasonably aspire to winnow are those that are filed without more than a hope that evidence to sustain them will be discovered or that defendants will settle to escape the burdens and embarrassment of prolonged litigation. Policymakers may prudently seek also to induce the prompt discontinuance of suits when initial expectations of ultimate success have been dashed by the evidence that has been produced.

This article proposes that assessments against attorneys become the principal device for winnowing derivative suits. To explain the reasons for this proposal, this article begins by analyzing the costs and benefits of derivative suits and the responsiveness of other winnowing devices to these costs and benefits.

contributions, which produced a temporary "litigation explosion." See Jones, An Empirical Examination of the Incidence of Shareholder Derivative and Class Action Lawsuits, 1917-1978, 60 B.U.L. REV. 306, $322-23$ (1980) [hereinafter cited as Jones, Incidence]. In one suit of this type, which became a precedent for dismissal of derivative suits, the facts had been brought to light by the company's own filings with the Securities and Exchange Commission and there was no hint of the directors' having sought to serve any purpose other than profits for shareholders. See Auerbach v. Bennett, 47 N.Y.2d 619, 393 N.E.2d 994, 419 N.Y.S.2d 920 (1979). Similarly, in Lasker v. Burks, 404 F. Supp. 1172 (S.D.N.Y. 1975), rev'd, 567 F.2d 1208 (2d Cir. 1978), rev'd, 441 U.S. 471 (1979), the faults charged had been openly disclosed by directors and no selfdealing was involved.

Statistical evidence of useless shareholders' suits may be found in Jones, An Empirical Examination of the Resolution of Shareholder Derivative and Class Action Lawsuits, 60 B.U.L. REv. 542 (1980) [hereinafter cited as Jones, Resolution ], even though it emphasizes the beneficial aspects of a majority of suits. More than $24 \%$ of the suits in Jones' study terminated with no benefits-nominal or otherwise- to the corporation; of the more than $75 \%$ that were terminated favorably to the plaintiff, the amount of benefit is known in less than a quarter; the benefits in some cases within this quarter may well have been less than the corporation's costs. Id. at 545-62. Jones' data do not separate shareholders' derivative suits from shareholders' class suits.

4. Defendants have strong incentives to settle, even when they believe that their chances of prevailing in a final judgment are very good. Usually they can settle for less than the litigation costs of continuing the suit. Under indemnification laws like those of Delaware, Del. CODE ANN. tit. 8, $\S 145$ (b) (1975), the corporation can indemnify the officers for litigation expenses and settlements when cases are settled but not when the officers are adjudged liable. Continuation of the suit exposes the officers to unfavorable publicity no matter how it is finally decided. Cf. Jones, Resolution, supra note 3, at 567.

For plaintiffs' attorneys, prolonging lawsuits costs time, but not much money out of pocket; the possibilities of receiving generous fee awards depends more on defendants' impulsions to settle than on plaintiffs' chances of winning.

5. In 1944 and succeeding years, New York and other states adopted requirements of security for expenses that were expected to curb derivative suits drastically. See Dykstra, supra note 1, at 88-89; Hornstein, The Death Knell of Stockholders' Derivative Suits in New York, 32 Calif. L. REv. 123 (1944); House, Stockholders' Suits and the Coudert-Mitchell Laws, 20 N.Y.U. L.Q. REV. 377 (1945). The 1979 decision of Auerbach v. Bennett, 47 N.Y.2d 619, 393 N.E.2d 994, 419 N.Y.S.2d 920, was seen by some commentators as another death knell to derivative suits. See Coffee \& Schwartz, supra note 3, at 284; Dent, The Power of Directors to Terminate Shareholder Litigation: The Death of the Derivative Suit?, 75 Nw. U.L. REV. 96, 107-09 (1980). But of. Cox, Searching for the Corporation's Voice in Derivative Sutts: A Critique of Zapata and the ALI Project, 1982 Duke L.J. 959. 


\section{Costs and Benefits of Derivative Suits}

To decide which suits should be garnered and which ones winnowed out, policymakers need to have some idea of the costs and benefits that may flow from these suits. Case law has frequently examined costs and benefits for the purpose of awarding attorney fees. In that context, costs are attorneys' work hours, and benefits are money paid into the corporate treasury or savings of money that would, without the suit, have been paid out. But there are many other ways of looking at costs and benefits, some of which have escaped attention because prevailing case law does not call for their calculation.

Policymakers need a more comprehensive view. With regard to benefits, they should contemplate not only gains of corporations on whose behalf suits are filed, but benefits enjoyed by other sectors of society. With regard to costs, they should consider not only the payments made by corporations and defendants, but also the diversion of time and resources and the shifting of costs to consumers, taxpayers, and others.

Discussion of these variables can be confusing because the persons aligned as defendants in derivative suits include not only the persons against whom sanctions are sought but also the corporation on whose behalf the suit is filed. In this article, "defendants" will signify only the persons against whom sanctions are sought; the corporation on whose behalf the suit is filed will be called the "represented corporation."

\section{A. A Public Policy Perspective}

1. Costs. From a public policy perspective, the cost of a derivative suit may be compared with the plume of a smokestack which dumps concentrated deposits over a small area near the stack and progressively more diffuse deposits as the distance from the stack increases. The most immediate fallout in derivative suits will be the fees of lawyers and other litigation participants. These are initially paid in varying proportions by the represented corporation, by defendant officers and directors, by insurance companies, and occasionally by plaintiffs. A less conspicuous but equally immediate cost of the derivative suit will be consumption of the time of the corporate officers and directors and their staffs and the consequent diversion of their best efforts from production and distribution.

But the fallout of expenses will not always rest where it first falls. Attorney fees disbursed by corporations will become part of the costs that diminish returns to investors, diminish compensation to employees, or increase prices to consumers, depending on which relationship is most vulnerable. Attorney fees disbursed by defendant officers will be partly reimbursed by the corporation or by insurance companies; those that are not reimbursed will enter into the compensation that corporations must pay to future officers or into the insurance premiums that corporations must pay for the protection of officers. Attorney fees disbursed by insurance companies will also be reflected in the premiums that nearly all corporations will pay for officers' and directors' liability insurance. Consequently, most of the 
attorney fees paid will enter into the costs of doing business and will be spread throughout the economy like other costs.

There will be still more remote and less measurable costs. To ward off derivative suits, directors will to some extent avoid making decisions that they would otherwise regard as advantageous to the corporation but which seem to involve dangers of derivative suits against themselves. When they do not avoid decisions, they will to some extent engage in a series of protective rituals such as obtaining the written opinions of "experts" who confirm their views and taking votes of "disinterested directors" and of shareholders in order to immunize their decisions from attacks on the ground of conflicts of interest. These rituals will contribute to the employment of lawyers and the inflation of operating costs.

Among the least tangible of costs will be the effect of the suit on the reputation of the corporation involved and of corporations in general. Most derivative suits involve charges of disloyal conduct by officers or directors in their own self interest or in the interest of the segment of shareholders that they represent. Whether true or false, the charges impair the confidence of employees, consumers, and voters in the integrity of corporate management. If employees, consumers, and voters believe that corporate managers betray even their own shareholders, they can be expected to distrust managers, particularly managers of defendant corporations, in other contexts. As a result, these constituencies will disbelieve what managers say about their abilities to pay wages, improve products, or reduce pollution.

2. Benefits. In a pattern similar to that observed with costs, benefits to the represented corporation begin with some clearly visible gains. The most obvious benefit will be money paid by or on behalf of defendants to the corporate treasury. More remote benefits will often be found in future savings that are expected to result from discontinuance of the practices that occasioned the suit.

Beyond these measurable gains will be the admonitory effects on future decisions. Directors, officers, and others who have been made to pay back their gains, to pay their lawyers, and to suffer the humiliation of unfavorable judgments or settlements will be more circumspect in the future. What is more important, officers of other corporations, admonished by their counsel, will take heed. As a result, investors in all corporations may realize greater returns; to the extent that they do, investment will be encouraged, expenses of corporations reduced, and productivity enhanced.

More remotely, maintenance of discipline among corporate executives will elevate the public perception of executives and will enhance their credibility in all their relations with employees, consumers, and voters.

Whether the enhancement of public confidence through enforcement of standards of managerial behavior outweighs the deterioration caused by exposure is a complicated question. It is somewhat like the question whether the Watergate exposure increased or diminished confidence in government. The short-term effects of derivative suits on public confidence are clearly negative, especially for the represented corporation. The long-term effects on confidence may be beneficial, but these gains will be slower in coming to the represented corporation than 
to others. In this respect, derivative suits tend to make the represented corporation and its constituencies pay for benefits that will be reaped in greater measure by other corporations and their constituencies.

\section{B. The Perspective of Disinterested Directors}

According to a doctrine of recent florescence, a shareholder's derivative suit will be dismissed on motion of the corporation if disinterested directors find that the maintenance of the suit is not in the "best interests of the corporation." 6 The factors that should be weighed in determining the corporation's best interests have not yet been settled. One of the clearest statements of what the disinterested directors have in fact considered is found in the New York decision of Auerbach $v$. Bennett. ${ }^{7}$ The plaintiff complained that corporate directors had approved or acquiesced in paying bribes to foreign government officials, thereby wasting the corporation's money and exposing it to penalties. A litigation committee composed of disinterested directors was appointed and concluded after investigation and consultation:

that none of the individual defendants had violated the New York State statutory standard of care, that none had profited personally or gained in any way, that the claims asserted in the present action are without merit, that if the action were allowed to proceed the time and talents of the corporation's senior management would be wasted on lengthy pretrial and trial proceedings, that litigation costs would be inordinately high in view of the unlikelihood of success, and that the continuing publicity could be damaging to the corporation's business. $^{8}$

From this passage, as well as from the general "best interests of the corporation" standard itself, one may infer that the costs and benefits to be considered by a directors' litigation committee are considerably narrower than those that should concern a lawmaker. On the cost side, the doctrine probably contemplates only the charges that will be disbursed by the corporation for its own defense or (by way of indemnity) for the defense of its officers and directors. It probably does not contemplate the charges that will be defrayed by liability insurance companies and will enter indirectly into the operating expenses of the represented corporation and all other corporations that buy similar insurance. Likewise, the loss of business that enters into the balance is only the loss of the represented corporation, not that of other corporations that share the obloquy (as Boeing may share the hostility generated by Lockheed's bribery).

On the benefit side, the only element referred to in the Auerbach opinion is the money that might be paid into the corporate treasury if guilty directors were successfully sued. Money saved by changes in managerial practices would probably be considered too, since it is often recognized in decisions on the amount of awards to plaintiffs' counsel. On the other hand, there is no suggestion that considerations

6. Dismissal on recommendation of disinterested directors seems to have been first recognized in the United States in Findley v. Garrett, 109 Cal. App. 2d 166, 240 P.2d 421 (1952), but was largely ignored in legal literature and in the practice until the flurry of cases embracing Burks v. Lasker, 441 U.S. 471 (1979), Auerbach v. Bennett, 47 N.Y.2d 619, 393 N.E.2d 994, 419 N.Y.S.2d 920 (1979), and Zapata Corp. v. Maldonado, 430 A.2d 779 (Del. 1981).

7. 47 N.Y.2d 619,393 N.E.2d 994,419 N.Y.S.2d 920 (1979).

8. Id. at $625-26,393$ N.E.2d at 997,419 N.Y.S.2d at 923. 
would include the beneficial admonitory effects on managerial responses to future temptations in the represented corporation. Clearly, no consideration would be given to admonitory effects on conduct of directors in other corporations. Likewise, there is no suggestion of credit for the gain in confidence that might result from a visible cleanup in corporate affairs.

In Delaware, disinterested directors are expected to make their decision on the same basis as in New York, but the court in which the motion for dismissal is made may review the decision on broader grounds. In Zapata Corp. v. Maldonado the court quoted with approval a federal court's framing of the question in these words: "The final substantive judgment whether a particular lawsuit should be maintained requires a balance of many factors-ethical, commercial, promotional, public relations, employee relations, fiscal as well as legal."9 The court reinforced this broad view of the components of the decision by stating, "[ $\mathrm{t}$ ]he Court of Chancery should, when appropriate, give special consideration to matters of law and public policy in addition to the corporation's best interests." 10 But the Second Circuit, while adopting the Delaware view that the court should reach its own decision on dismissal, adopted a valuation scheme much like that of Auerbach. ${ }^{11}$

Under both the New York and Delaware views, the balance of costs and benefits apparently relates to the question whether the derivative suit should continue to be maintained rather than whether it should have been started. ${ }^{12}$ The difference, which may be substantial, is illustrated by Lewis $v$. Anderson. ${ }^{13}$ In this case, the filing of a derivative suit was followed by appointment of a litigation committee, which recommended that the directors' actions of which the plaintiff complained be submitted to the shareholders for ratification. ${ }^{14}$ Upon ratification, the

9. 430 A.2d 779, 788 (Del. 1981) (quoting Maldonado v. Flynn, 485 F. Supp. 274,285 (S.D.N.Y. 1980), modified, 671 F.2d 729 (2d Cir. 1982)).

10. Id. at 789. It is possible that this broader review of the disinterested directors' decision will be made only in cases in which a prior demand was excused because the board had no majority of disinterested directors. See id. at 784 n.10.

11. See Joy v. North, 692 F.2d 880, 892 (2d Cir. 1982) (applying Connecticut law), cert. denied, 102 S. Ct. 1498 (1983). The only benefit recognized was the amount of recoverable damages. The costs to be considered were corporate expenditures for attorney fees, corporate indemnification of defendants' expenses, diversion of executives' efforts, and loss of profits through unfavorable publicity.

12. See Zapata, $430 \mathrm{~A} .2 \mathrm{~d}$ at 785 :

The question to be decided becomes: When, if at all, should an authorized board committee be permitted to cause litigation, properly initiated by a derivative stockholder in his own right, to be dismissed?. . Even when demand is excusable, circumstances may arise when continuation of the litigation would not be in the corporation's best interest.

Auerbach, 47 N.Y.2d at 630,393 N.E.2d at 1000,419 N.Y.S.2d at 926 :

Then subsequent to the service of the complaint there came the report of a special litigation committee, particularly appointed by the corporation's board of directors to consider the merits of the present and similar shareholders' derivative actions, and its determination that it would not be in the best interests of the corporation to press claims against defendants based on their possible first-tier liability.

See also Joy v. North, 692 F.2d 880, 892 (2d Cir. 1982), cert. denied, 103 S. C. 1498 (1983): "Where the court determines that the likely recoverable damages discounted by the probability of a finding of liability are less than the costs to the corporation in continuing the action, it should dismiss the case."

13. 615 F.2d 778 (9th Cir. 1979), cert. denied, 449 U.S. 869 (1980). The issue of attorney fees was subsequently litigated in Lewis v. Anderson (II), 509 F. Supp. 232 (C.D. Cal. 1981), affd, 692 F.2d 1267 (9th Cir. 1982).

14. Lewis (II), 509 F. Supp. at 234. 
committee decided that further prosecution of the litigation would not be in the company's best interests. ${ }^{15}$ Plaintiff concluded he could not prove the lack of good faith or independence on the part of the committee necessary for the litigation thus to proceed but joined his motion for dismissal with prejudice with a petition for a fee award. ${ }^{16}$ The court awarded a fee because the filing of the suit had had a beneficial effect in vindicating the shareholders' right to be consulted, although the further maintenance of the suit, after the shareholders' ratification of directors' action, would not have served any corporate interest. ${ }^{17}$

In contrast, a derivative suit may have negligible potential for conferring a net benefit, even when the acts of which it complains were clearly wrong. In Ambramowitz v. Posner, ${ }^{18}$ the corporation had taken corrective action before the plaintiff even made a preliminary demand. The Securities and Exchange Commission (SEC) had obtained a consent decree for the repayment of $\$ 600,000$, and an audit committee had recommended that the corporation demand an additional $\$ 1,000,000$ from the defendants. ${ }^{19}$ The plaintiff's suit seems to have been an attempt to climb on a bandwagon that was already rolling.

C. The Perspective of the Wood Report

Although ink has flowed freely for a century on the pros and cons of derivative suits, there have been few examinations of their vital statistics. The first systematic survey was the Wood report of $1944 .^{20}$

The outstanding disclosure of this report was that a majority of derivative suits result in dismissal or discontinuance without any possible benefit to the represented corporation, while a very small percent result in plaintiffs' victories, and an intermediate percent result in settlements of varying value. ${ }^{21}$ Wood noted the minuscule amounts of benefits to plaintiff shareholders, ${ }^{22}$ which he contrasted with large awards to plaintiffs' attorneys. ${ }^{23}$ His conception of benefits to shareholders seems to have been limited to cash gains to the treasury. He observed that most of the significant contributions to corporate treasuries resulted from correction of unintentional errors of directors, implying that the suits could have few admonitory effects. ${ }^{24}$

\section{The Perspective of the Jones Report}

The most recent light on the outcomes of derivative suits has been cast by the report of a survey by Thomas M. Jones based on cases occurring in the 1970's. ${ }^{25}$

\footnotetext{
15. Id. at 235 .

16. Id.

17. Id. at 238 .

18. 672 F.2d 1025, 1027-28 (2d Cir. 1982).

19. Id.

20. F. Wood, Survey and Report Regarding Stockholders' Derivative Suits (1944) (prepared for the Special Committee on Corporate Litigation, Chamber of Commerce of the State of New York).

21. Id. at $32-35$.

22. Id. at $49-54$.

23. Id. at $78-84$.

24. Id. at $36-43$

25. Jones, Incidence, supra note 3, at 306; Jones, Resolution, supra note 3, at 542.
} 
All of the corporations surveyed were subject to the Securities and Exchange Act of $1934^{26}$ and were therefore required to report publicly the outcomes of derivative suits and the major elements of settlement agreements. The study did not include closely held corporations, which comprised a majority of those covered by the Wood report.

The Jones report showed that in the 1970's, as in the 1930's, most of the surveyed suits were settled without going to final judgment of recovery or dismissal. ${ }^{27}$ Unlike the Wood report, the Jones report disclosed the content of the settlements and found that most of them involved some specific benefit to the represented corporation. ${ }^{28}$

Jones' report, like Wood's, ${ }^{29}$ showed that very few suits came to final judgment for the plaintiffs. Jones' percentage of plaintiffs' judgments was $0.6 \%$, 30 lower than Wood's $2 \%$ for publicly held corporations and $5 \%$ for closely held corporations. ${ }^{31}$ On the other hand, Jones found a much higher percent of suits that won something for the represented corporations-a total of more than $75 \% .{ }^{32}$ Roughly $71 \%$ were settled with some benefit, $4 \%$ ended with defendants conforming to plaintiffs' demands, and $0.6 \%$ ended with contested judgments for plaintiffs. ${ }^{33}$ The settlements generally included some restitution to the corporation or an injunction or agreement prohibiting future misfeasances plus occasionally a structural change such as appointment of independent directors. ${ }^{34}$ Jones inferred that these suits were beneficial on balance, viewing reforms in corporate governance as the most significant consequence. ${ }^{35} \mathrm{He}$ did not give any express consideration to costs in defendants' attorney fees, in diversion of executives' time, in augmentation in the corporation's payments for insurance and for compensation of officers and directors, or in the corporation's loss of repute.

The fact that consent judgments contain some payments and injunctions is not very conclusive as to a beneficial balance when one considers that under court supervision a settlement can hardly be made without these elements. There is a substantial possibility that some suits lead to settlements not because of their merits but because of the plaintiff's ability to harass the corporation with endless demands for discovery. Jones' report disclosed that in many cases the measured benefits were quite modest, ${ }^{36}$ although he emphasized the large size of a small minority of settlements. ${ }^{37}$

Jones also showed that a significant minority of suits-about 20\%-ended in

\footnotetext{
26. Ch. 404,48 Stat. 881 (1934) (codified as amended at 15 U.S.C. $\$ 78$ (1976 \& Supp. V. 1981)).

27. Jones, Resolution, supra note 3 , at 545 .

28. Id. at $547-62$.

29. F. Wood, supra note 20 , at 32 .

30. Jones, Resolution, supra note 3 , at 545.

31. F. Wood, supra note 20 , at 32 .

32. Jones, Resolution, supra note 3 , at 545 .

33. Id.

34. Id. at $547-62$.

35. Id. at 569 .

36. Id. at 530-51.

37. Id. at 547-62.
} 
dismissal with no recovery and no settlement. ${ }^{38}$ He made no further comment on these suits or on their implications for the state of the law on derivative suits.

The combination of Jones' cases where nothing was recovered with those that were settled with small direct benefits leaves a strong suspicion that some suits that should be deterred are not now being stopped. On the other hand, the evidence is impressive that a substantial number of filed suits are beneficial. One would like to know whether there are also potential suits that would be beneficial if filed, but no survey throws any light on this question.

\section{III}

\section{Winnowing Without Fee Control}

Lawmakers, including judicial rulemakers, have been engaged for approximately a century in devising means of winnowing out derivative suits that will be more detrimental than beneficial. We will consider first the methods that are not centered on fees.

\section{A. Winnowing by Characterization}

The earliest kind of winnower was one that characterizes some categories of plaintiffs as being more likely to file meritless than meritorious claims. The contemporaneous ownership rule is an early example of this mode. It first appeared as a device for preventing the fabrication of diversity of citizenship in federal courts ${ }^{39}$ but has now been adopted by state courts as a merit-selector. ${ }^{40}$ In closely held corporations the contemporaneous ownership rule must be a powerful eliminator since old friends and relatives of abusive managers will be slow to attack them. But that does not make it a good selector; it probably protects some perpetrators of outrageous mismanagement. ${ }^{41}$

In publicly held corporations, the rule is largely inoperative since a contemporaneous shareholder can usually be found even if the principal instigator is not one. But the rule may become operative when the publicly held corporation becomes private through a takeover of all or most of its shares. ${ }^{42}$

Another kind of winnowing by characterization occurs when the suit is dismissed because the plaintiff has "dirtied his hands" by participating in the wrongful acts or because the plaintiff had a confidential relationship with the perpetrators. ${ }^{43}$ These dismissals presumably teach moral lessons to plaintiffs but have

\footnotetext{
38. Id. at 545 .

39. Hawes v. Oakland, 104 U.S. 450 (1881).

40. Del. Code ANN. tit. 8, § 327 (1975); N.Y. Bus. CoRP. LaW § 626(b) (McKinney 1963); MODEL Business CORP. ACT $\S 49$ (1979).

41. Cf. Harbrecht, The Contemporaneous Ownership Rule in Shareholders' Derivative Suits, 25 U.C.L.A. L. REV. 1041 (1978).

42. See Bangor Punta Operations v. Bangor \& Aroostook R.R., 417 U.S. 703 (1974), in which a suit brought by the corporation itself was dismissed because $98.3 \%$ of the shares had been sold since the misfeasance occured. Whether the other $1.7 \%$ of the shareholders could have maintained a suit was not discussed.

43. See Richardson v. Hamilton Int'l Corp., 469 F.2d 1382 (3d Cir. 1972), cert. denied, 411 U.S. 986 (1973) (former counsel who had advised corporation's executives barred from maintaining derivative action against those executives); Connors v. Conners Bros. Co., 110 Me. 428, 86 A. 843 (1913) (former treasurer who had disbursed funds for bribes could not maintain derivative suits against other executives
} 
no value in separating meritorious complaints from meritless ones. On the contrary, confidants and confederates are likely to have convincing evidence at their disposal.

An attenuated form of winnowing by characterization is found in the requirement that security for expenses be posted by holders of securities worth less than a set dollar amount (e.g., $\$ 50,000)^{44}$ or of fewer securities than a set percentage of shares (e.g., 5\%). ${ }^{45}$ Shareholders who are below these thresholds are subject to burdensome security requirements that presumably deter some of them from suing. In practice, the security requirement has not had much effect in publicly held corporations because courts have allowed plaintiffs to meet the threshold by aggregating holdings, including holdings of plaintiffs who join after the suit is filed, ${ }^{46}$ but the requirement is likely to be a powerful eliminator in closely held corporations when other shareholders who would be willing to join cannot be found.

While each of the characterization devices serves some intelligible purpose, none of them is well suited to distinguishing meritorious derivative suits from meritless ones. The fact that a plaintiff has recently bought his shares, was formerly a confederate of the defendants, or holds few shares has no logical correlation with any balance of costs and benefits of a suit on behalf of the corporation against accused defendants.

\section{B. Winnowing by Preliminary Judicial Evaluation}

Under California law, a defendant can call for a preliminary determination of whether there is a reasonable possibility that the prosecution of the suit will benefit the corporation and its shareholders. In form, he moves for an order that the plaintiff furnish security. ${ }^{47}$ If the court finds that the plaintiff has no reasonable possibility of success, the plaintiff must furnish security. The decision usually determines whether the suit will continue, since plaintiffs are unlikely to furnish security after the court in which they must prosecute has decided that there is no reasonable possibility of their winning.

The suits that are winnowed out by this device probably deserve their fate. From the reported cases, it appears that the judge examines voluminous docu-

who had arranged and paid bribes). But of. Kullgren v. Navy Gas \& Supply Co., 112 Colo. 331, 149 P.2d 653 (1944) (rejecting defense of unclean hands).

44. N.Y. BuS. CORP. LAW $\S 627$ (McKinney Supp. 1982-83) (authorizing a requirement for security unless the plaintiff owns either $5 \%$ of a class of shares or shares worth $\$ 50,000)$.

45. WIS. STAT. ANN. $\$ 180.405(4)$ (West 1957) (authorizing a security requirement unless plaintiffs hold $3 \%$ of a class of shares, without any dollar threshold).

46. See Security for Expenses in Shareholders' Derivative Suits: 23 Years' Experience, 4 Colum. J.L. \& SoC. PROBS. 50, 62-63 (1968).

47. Cal. CoRP. CODE $\S 800$ (c) (West Supp. 1983). The motion to require bond may be based on either or both of the following grounds:

(1) That there is no reasonable possibility that the prosecution of the cause of action alleged in the complaint against the moving party will benefit the corporation or its shareholders.

(2) That the moving party, if other than the corporation, did not participate in the transaction complained of in any capacity.

The statute further authorizes hearings at which written and oral evidence may be received and considered. Id. at $\$ 800$ (d). 
ments and depositions before reaching a decision; ${ }^{48}$ one opinion refers to 810 pages of oral testimony. ${ }^{49}$

But the procedure is unlikely to spare corporations most of the expense of baseless suits. To determine whether the suit has a reasonable possibility of benefit, the judge must examine most of the same evidence that he would examine in order to decide the case on its merits. ${ }^{50}$ Consequently, the defendants incur most of the expenses of a lawsuit before the suit can be dismissed.

Also, in relatively few suits will the judge be able to determine that no reasonable possibility of benefit exists; if the plaintiff can produce affidavits creating substantial questions of fact, the case will go forward. In the cases where security has been required, the court has found that on the conceded facts the plaintiff had no cause of action.

In the cases that go forward, the defendants will have to produce at the trial the same evidence that has already been reviewed in the ruling on security. In effect, the defendants' motions for security will have subjected them to two trials instead of one. Far from deterring the filing of baseless suits, the procedure gives plaintiffs opportunities to test their cases without incurring any liability for defendants' costs.

\section{Winnowing by Decision of Disinterested Directors}

The newest development in the regulation of derivative suits is dismissal on motion of the corporation pursuant to a finding by a litigation committee composed of disinterested directors that the maintenance of the suit is not in the corporation's best interests. ${ }^{51}$ The principal merit of this device is its potential for getting rid of suits of which the principal purpose is embarrassment of the executives involved. This potential has been nicely illustrated in some cases charging officers and directors with acts that had already been the subject of investigation and recommendation by internal committees and even of reports to the SEC. ${ }^{52}$

How this device will be articulated in later cases remains to be seen. It appears to have two inherent shortcomings.

The primary weakness of reliance on a litigation committee's decision is its propensity for bringing about dismissal of beineficial suits as well as of detrimental

48. See Marble v. Latchford Glass Co., 205 Cal. App. 2d 171, 22 Cal. Rptr. 789 (1962); Thomas v. Summers Gyroscope Co., 160 Cal. App. 2d 234, 324 P.2d 893 (1958); Olson v. Basin Oil Co., 136 Cal. App. 2d 543, 288 P.2d 952 (1955).

49. Thomas v. Summers Gyroscope Co., 160 Cal. App. 2d 234, 240, 324 P.2d 893, 897 (1958).

50. See cases cited supra note 48.

51. See supra note 6.

52. See Abramowitz v. Posner, 672 F.2d 1025 (2d Cir. 1982) (plaintiff's demand had been preceded by a consent decree in favor of the SEC ordering repayment of $\$ 600,000$ and by an adult committee recommendation to seek repayment of additional sums); Gall v. Exxon Corp., 418 F. Supp. 508 (S.D.N.Y. 1976) (litigation committee investigated payments and found the chief executive had earlier ordered discontinuance); Lasker v. Burks, 404 F. Supp. 1172 (S.D.N.Y. 1975), rev'd, 567 F.2d 1208 (2d Cir. 1978), rev'd, 441 U.S. 471 (1979) (directors had already sued and recovered a settlement of more than $\$ 5,000,000$ on account of the incident involved); Auerbach v. Bennett, 47 N.Y.2d 619, 393 N.E.2d 994, 419 N.Y.S.2d 920 (1979) (illegal payments had been previously investigated by an audit committee and reported to shareholders and to the SEC); of. Rosengarten v. IT\&T Corp., 466 F. Supp. 817 (S.D.N.Y. 1979) (questionable payments had been previously reported to shareholders). 
ones. ${ }^{53}$ In contemplating the costs of continuing the suit, committee members will be appalled by the prospective legal expenses of the corporation and of the defendant directors and by the diversion of executives' time from more productive activities. They will perceive themselves as able to obtain from the defendant directors all the restitution and changes of practice that a court would eventually order, and at much less cost. If the other directors have been prescient, they will have delegated authority to the committee to decide not only on continuance of the suit, but also on remedial measures to be carried out within the corporation. Under the New York rule, as formulated in the Auerbach case, ${ }^{54}$ even the most meritorious suits seem sure to be dismissed, with the consequence that similar suits will no longer be filed. Whether the same result will follow in Delaware will depend on how the courts' own business judgments are exercised.

The second weakness of dismissal on the motion of disinterested directors arises because considerable expense and diversion of resources are incurred before the case is dismissed. These costs will be felt most sharply in Delaware, where a court will review the costs and benefits of maintaining the suit before making its decision on dismissal. ${ }^{55}$ To make this review, the court will be required to examine volumes of written evidence, and perhaps hear witnesses, while corporate executives and attorneys for the corporation will have to marshal evidence. As under the California procedure for a preliminary determination of probability of success, ${ }^{56}$ there will be a minitrial to decide whether there should be a full trial. The meritless suit will still impose heavy costs on the corporation and indirectly on its investors, employees, or customers.

Even in New York, where the courts are instructed to examine only the disinterest of the litigation committee, the examination may be extensive. As the Court of Appeals observed,

What evidentiary proof may be required to this end will, of course, depend on the nature of the particular investigation, and the proper reach of disclosure at the instance of the shareholders will in turn relate inversely to the showing made by the corporate representatives themselves. The latter may be expected to show that the areas and subjects to be examined are reasonably complete and that there has been a good-faith pursuit of inquiry into such areas and subject. ${ }^{57}$

In summary, the decision of independent directors appears to be an ineffective means of winnowing derivative suits. This device will eliminate many meritorious suits by reason of the deference paid by judges to the opinions of "independent" directors. Meritorious suits that might surmount this hurdle will be impeded by the expense of the double trial-one to decide whether the suit proceeds and the other to decide whether it prevails.

53. Cf. Coffee \& Schwartz, supra note 3, at 280-300; Cox, supra note 5, at 962-63; Dent, supra note 5, at 109; Steinberg, The Use of Special Litigation Committees to Terminate Shareholder Derivative Sutts, 35 U. MIAMI L. REV. 1 (1980).

54. See supra text accompanying notes 6-9.

55. Zapata Corp. v. Maldonado, 430 A.2d 779 (Del. 1981); see discussion supra text accompanying notes $9 \cdot 10$.

56. See supra note 47 and accompanying text.

57. Auerbach v. Bennett, 47 N.Y.2d 619, 634, 393 N.E.2d 994, 1003, 419 N.Y.S.2d 920, 929 (1979). 


\section{IV \\ Winnowing By Fee Award and Assessment Practices}

\section{A. Dynamics of Fee Practices}

The winnowing devices discussed above operate to facilitate the dismissal of meritless suits. They do not work very well, partly because plaintiffs' lawyers are still willing to take long chances of winning, partly because they do not save defendants from expense in obtaining dismissals, and partly because defendants sometimes prefer settling to incurring the costs of obtaining dismissal.

Fee practices, in contrast, operate on the motivations of attorneys in filing and maintaining suits. When fee considerations prevent the initial filing of the suit, defendants are spared even preliminary expenses. By motivating attorneys to refrain from filing meritless suits, the possibility of fee shifting invokes the judgment of the attorneys themselves to determine whether they will be found to have filed in the expectation of winning or of extracting a nuisance settlement.

Fee orders are made at the conclusion of a suit after all the evidence has been heard. Instead of guessing in advance which of the allegations will be sustained by testimony, the judge knows which allegations were sustained in actuality. Fee orders are retrospective with regard to the suit in which they are made, but they have prospective effect on suits to be filed in the future because they affect attorneys' decisions to file or not to file.

This article examines how the ways in which fee practice can be made to diminish the incentives for, and provide deterrents to, the filing of derivative suits that lack merit.

\section{B. Winnowing by Controlling Awards to Plaintiffs' Attorneys}

To most onlookers, the strongest incentive for the filing of derivative suits without regard to their merits is the enormity of fee awards that occasionally make the headlines; one award of nearly $\$ 2,000,000$ is on record. ${ }^{58}$ These huge fee awards raise two quesions-whether they create incentives for filing suits that lack merit, and whether they are larger than necessary to motivate the filing of suits that are meritorious.

It seems inherently likely that high awards motivate the filing of suits that lack merit. If attorneys and judges were completely wise, fee awards would not have this effect, since judges would refuse to make awards in meritless suits, and attorneys, knowing the judges' policies, would not file the suits. But in a world in which merits and probabilities are hard to measure, fees that exceed normal returns for hours of work are likely to motivate the filing of forlorn causes. To minimize the temptation to file suits with little merit, awards in the meritorious suits should be held to the minima that are necessary to induce suits that are meritorious.

One source of excessive fees is the award calculated as a percentage of the

58. Zenn v. Anzalone, 46 Misc. 2d 378, 259 N.Y.S.2d 747 (Sup. Ct. 1965). For a compilation of reported awards, see Cole, Counsel Fees in Stockholders' Derivative and Class Actions-Homstein Revisited, 6 U. RiCH. L. REV. 259, 283-85 (1972). 
benefit conferred on the represented corporation. ${ }^{59}$ When millions of dollars are involved, as is often the case in derivative suits, customary percentages may result in fees that reward attorneys for their time at a rate far greater than they could earn in any other line of legal work. 60 One can hardly doubt that these awards inspire filing some long-shot lawsuits. ${ }^{61}$

Percentage awards are sometimes defended on the ground that they are presumably fair, since they are calculated in the same way as contingent fees to which personal injury claimants subscribe of their own free will. This rationale is obviously insufficient. The market for the services of personal injury lawyers is not so open and informed that one needs to have any faith in the fitness of the rates charged. Even if percentage compensation is appropriate for individual lawsuits, it is not likely to be equally fitting for corporate lawsuits where the amounts involved are multiplied by the thousands of investors whose interests may be affected. Finally, appropriate compensation for services voluntarily purchased has no necessary relation to appropriate compensation for services that are rendered to involuntary beneficiaries (the passive shareholders) or resisting beneficiaries (the represented corporations). In the law of restitution, officious intermeddling is generally not compensated at all. ${ }^{62}$

Courts are generally cognizant of the inefficiency of percentage awards; the past decade has witnessed a strong movement toward basing fees on hours of work devoted to the case. ${ }^{63}$ This approach introduces two problems-the setting of the hourly rate and its multiplication on account of difficulty or risk.

Sometimes the hourly rate is set at the "prevailing rate" that is generally earned by other attorneys in the same kind of work. ${ }^{64}$ This formula leads the court to an extensive exploration of the earnings of attorneys who are established practitioners in the area, tempered by a difficult evaluation of the experience and reputation of the petitioning attorney.

Forsaking "prevailing rates," courts sometimes take the petitioner's customary "billing rate."65 The opinions do not show just how the billing rate is proved. Many firms that file derivative suits derive most of their income from other representative and contingent fee suits, so that they have few occasions to bill. ${ }^{66}$ The

59. The percentage method was generally taken as basic until the late 1970's. See Cole, supra note 58, at 270; Dawson, Lawyers and Involuntary Clients in Public Interest Litigation, 88 HARV. L. REV. 849, 876 (1975); Hornstein, Legal Therapeutics: The "Salvage" Factor in Counsel Fee Awards, 69 HARV. L. REV. 658 (1956).

60. See Ripley v. International Rys., 16 A.D.2d 260, 227 N.Y.S.2d 64, affd mem., 12 N.Y.2d 814,187 N.E.2d 131, 236 N.Y.S.2d 64 (1962); Zenn v. Anzalone, 46 Misc. 2d 378, 259 N.Y.S.2d 747 (Sup. Ct. 1965). The movement from percentages to value of hours worked seems to have been touched off by some direct class actions for antitrust violations, where benefits were estimated in the tens of millions or hundreds of millions of dollars. See Hammond, Stringent New Standards for Awards of Attorney's Fees, 32 BuS. LAW 523 (1977); Herzel and Hagan, Plaintiffs' Attomeys' Fees in Derivative and Class Actions, 7 LiTIGATION 25 (1981); Mowrey, Attomey Fees in Securities Class Actions and Derivative Suits, 3 J. CoR P. L. 267, 334-48 (1978).

61. Cf. Dawson, supra note 59, at 929: "The court-directed game of roulette that has thus emerged has the same attractions for the adventurous lawyer as those to be found in other games of chance."

62. Cf. Dawson, supra note 59 , at 857 .

63. See generally Mowrey, supra note 60, at 334-48; Hammond, supra note 60 .

64. See, e.g., Tranberg v. Tranberg, 456 F.2d 173, 175 (3d Cir. 1972).

65. See Lindy Bros. Builders v. American Radiator Corp., 487 F.2d 161, 167 (3d Cir. 1973).

66. Cf. Hammond, supra note 60, at 527; Mowrey, supra note 60, at 324-25. 
rate at which they bill Exxon or Prudential on the rare occasions when these corporations employ them is a poor indication of the rate of compensation that would induce them to file meritorious derivative suits. A better indication would be the firm's business income, as shown on a tax return, divided by the number of hours available for client service.

After choosing a base rate, courts sometimes multiply it in order to compensate plaintiffs' attorneys for the chance that a suit, although meritorious, will not succeed. ${ }^{67}$ If an excessive rate has been chosen, multiplying it compounds the error. If, however, a realistic rate has been chosen, some multiplication is appropriate.

The question of how much to multiply is a difficult one which can barely be touched on here. ${ }^{68}$ Multiples up to four have been used, although multiples of 1.5 or less are more common. ${ }^{69}$ A plausible argument can be made for multiples up to 1.99 on the ground that attorneys should be encouraged to file suits that have better than an even chance of succeeding. In representative suits, where the prospective beneficiaries are unwilling or involuntary, one can hardly argue for bringing suits at the beneficiaries' expense which have no better than an even chance of helping them.

If meritless derivative suits continue to be filed and maintained even after all the excesses have been squeezed out of awards to plaintiffs' attorneys, judges should not conclude that awards have not been squeezed enough. Some attorneys will still overestimate their chances of winning. After they have invested time in the initial preparation and filing, they will weigh their chances of winning not against their total investment, but against the incremental investment that might possibly bring forth a settlement offer. If the first increment of effort is unproductive, the temptation to salvage the prior efforts by one more increment is hard to resist, and so the hopeless case will drag on and on. Courts cannot control this phenomenon merely by reducing awards in meritorious cases; they need to apply deterrents to cases that lack merit.

\section{Winnowing by Assessment Against Nominal Plaintiffs}

Critics recurrently suggest that courts in the United States should adopt the "English Rule" making plaintiffs liable for defendants' attorneys' fees when defendants win their cases. Translating the English rule to practice in the United States would be complex, since the fees for which English losers become liable are more strictly controlled than the fees that U.S. lawyers charge their clients. ${ }^{70}$

Even if a reasonable scale of assessable fees could be established, the system would probably not be a useful selector. One basic difficulty is that plaintiffs cannot fairly be blamed for unjustified suits. Their lawyers are the ones who can tell, if anyone can, whether a suit is justified. ${ }^{71}$ Nominal plaintiffs are unlikely to

67. Hammond, supra note 60 , at 528; Mowrey, supra note 60 , at 339 .

68. For a deeper exploration, see Leubsdorf, The Contingency Factor in Attorney Fee Awards, 90 YALE L.J. $473(1981)$.

69. See Mowrey, supra note 60 , at $339 \&$ n. 515.

70. Goodhart, Costs, 38 YALE L.J. 849, 856-58 (1929).

71. See Rothenberg v. Security Management Corp., [1982-1983 Transfer Binder] FED. SkC. L. REP. 
overrule their attorneys when the plaintiffs' stakes are so much smaller than the corporation's cause of action. Penalizing plaintiffs may teach them to distrust lawyers, but will not have much effect on the filing of derivative suits because few plaintiffs are repeaters; it is their lawyers who must learn the lesson.

If judges feel this way about assessing fees against plaintiffs, they will find ways of avoiding assessments. Out of a mass of charges, they will find one that justifies the suit. Minuscule justifications of this sort are recurrently encountered in decisions awarding fees to plaintiff's' counsel who have won on only one or two minor issues. $^{72}$

\section{Winnowing by Requiring Security for Attorneys' Fees}

The Wood report of 1944 was quickly followed by a wave of legislation requiring certain plaintiffs to post security for defendants' attorneys' fees. ${ }^{73}$ The characterization of plaintiffs who are and who are not impaled on this requirement has already been addressed, and attention is now directed to its efficiency as a selector among those who are impaled. The legislative supposition, if rational, must have been that the impaled plaintiffs with meritorious suits would post their bonds and press ahead while plaintiffs with meritless claims would abandon them. ${ }^{74}$

We have no data on how the law has affected the behavior of plaintiffs who did not succeed in circumventing the security requirement by aggregating sufficient holders, and very little evidence of how the courts have acted in assessing defendants' fees against plaintiffs. When the dynamics of the rule are contemplated, it seems unlikely to be an efficient selector of suits. The amounts of defendants' attorneys' fees are often higher than the value of shares required to escape the requirement. For example, a holder of $\$ 5,000$ worth of shares might have to risk incurring a $\$ 50,000$ assessment to assert his own and his fellow-shareholders' rights. Considering the unpredictability of litigation outcomes, a normally prudent investor would probably refrain from filing even a very plausible complaint if required to post security for defendants' expenses.

The only shareholder who would be likely to risk posting security would be one who had a chance of gaining in some other role. A shareholder whose attorney is her son, for example, might be willing to risk a $\$ 50,000$ security deposit in hope of her son's winning $\$ 1,000,000$.

\section{E. Winnowing by Assessments against Plaintiffs' Attorneys}

As a deterrent against unproductive litigation, assessments against offending

(CCH) I 99,038 (N.D. Ga. 1982), where fees were assessed against two plaintiffs, of whom one was not a shareholder and the other had not read the complaint.

72. See, e.g., Jones, Resolution, supra note 3 , at 567.

73. See Dykstra, supra note 1, at 88-89 \& n.96, citing security for expenses statutes in Maryland (1945), New Jersey (1945), Pennsylvania (1945), Wisconsin (1945), California (1949), North Dakota (1960), Colorado (1963), Nebraska (1963), Arkansas (1966), Florida (1966) Texas (1966), and Washington (1966).

74. For a more cynical view that the legislation was designed to deter all suits by small shareholders, see Hornstein, supra note 5. 
attorneys have attained a sudden prominence in recent years. ${ }^{75}$ Assessments have unique potential for controlling detrimental derivative suits. Like limitations on fee awards, they serve to motivate the individuals - attorneys-most likely to make the crucial decisions about filing and maintaining suits. Unlike limitations of awards, they serve primarily to deter the suits that ought to be eliminated without necessarily reducing incentives for the ones that ought to be preserved. We will examine how assessments might be used to deter unproductive derivative suits and then inquire as to what changes in the law would be required to authorize the making of assessments for this purpose.

1. A Program for Assessments Against Plaintiffs' Attorneys. The effectiveness of assessing expenses against plaintiffs' attorneys will depend on the criteria of assessment. The criteria should be designed to deter the useless suits without scaring away the useful ones. Critical elements will include the measure of net benefits and the probability of the benefits occurring.

a. The measures of benefit. The benefit with which the judge is concerned in assessing fees against plaintiffs' attorneys should be the prospective benefit to society. This is quite a different matter from the benefits considered in various other connections. ${ }^{76}$

It is different, first of all, from the benefit to the corporation, as measured in awarding fees to successful plaintiffs' attorneys. That benefit is measured by results; attorneys receive some share of what they have actually produced. ${ }^{77}$ Assessments, on the contrary, should be based on what was foreseeable to the attorneys when they filed or maintained the suits.

Prospective social benefit is also different from the best interests of the corporation, which are considered by disinterested directors in deciding whether to move for dismissal of a derivative suit. ${ }^{78}$ It is different partly because judges will view, much more objectively than directors, the need for outside intervention to correct mismanagement. More fundamentally, it is different because social benefits include admonitory effects that reverberate through hundreds or thousands of corporations in addition to the one involved in the suit.

The test of prospective social benefit is more easily met than the test of the benefit realized by the represented corporation or the test of best interests of the corporation, but it is a stricter test than is required to survive a defendant's motion for dismissal or summary judgment. If a complaint charges illegal behavior, it will survive a motion for dismissal or summary judgment even though the interests of

75. See Roadway Express v. Piper, 447 U.S. 752 (1980) and numerous casenotes on it; Ryan, Hazards of Vexatious Conduct in Litigation, 30 Der. L.J. 123, $127-40$ (1981); Comment, Sanctions Imposed by Courts on Attorneys Who Abuse the Judicial Process, 44 U. CHI. L. REv. 619, 623-36 (1977); Note, Altomeys' Liability to Clients' Adversaries for Instituting Frivolous Lawsuits: A Reassertion of Old Values, 53 ST. JoHN's L. REV. 775 (1979).

76. Compare Zapata Corp. v. Maldonado, 430 A.2d 779 (Del. 1981) (costs and benefits of maintaining suit); see supra text accompanying notes 9-10.

77. Leubsdorf, supra note 68; cf. Dewees, Prichard \& Trebilcock, An Economic Analysis of Cost and Fee Rules for Class Actions, $10 \mathrm{~J}$. LEGAL STUD. 155 (1981).

78. Compare Auerbach v. Bennett, 47 N.Y.2d 619, 393 N.E.2d 994, 419 N.Y.S.2d 920 (1979); Zapata Corp. v. Maldonado, 430 A.2d 779 (Del. 1981). 
the corporation are unlikely to be advanced by the suit. ${ }^{79}$ This is probably the principle that inspired some of the suits challenging questionable foreign payments. ${ }^{80}$ In some of those cases, the payments had already been reported to the SEC so that the Commission or the U.S. Department of Justice could be expected to take any measures that would be in the public interest. Under such circumstances, the test of prospective social benefit would lead to assessing plaintiffs' attorneys with some of the expenses of defendants.

A puzzling problem is the weight that should be given to unreasonable defense expenditures. There is no doubt that the essential costs of attorneys who advise and appear for the represented corporation and for the real defendants should be considered. Even if the defendants are liable, they need counsel to participate in determining the extent of their liability. The difficulty arises when defendants incur large expenses in denying liability that is eventually proved and engaging in dilatory or vexatious tactics of obstruction. Are plaintiffs' attorneys bound to weigh these costs against benefits in deciding whether to file a derivative suit?

The better answer seems to be the affirmative one. Plaintiffs' attorneys must make their decisions in view of the imperfect system of justice that exists. If they can reasonably foresee that more money will be spent in litigation than will be gained-even when the broader social effects are included-the suit should not be filed.

b. The probability of benefit. Assuming that plaintiffs' attorneys can foresee a probability of social benefit from a derivative suit, the question arises, what degree of probability should move them to action? Is it a virtual certainty, a preponderance of likelihood, or only a realistic possibility? These are vague measures at best, but a judge who is charged with assessing fees must have some degree of probability as a standard. Here again, the appropriate degree of probability is quite different from that employed for other purposes.

Under the Model Rules of Professional Conduct of the American Bar Association, litigation is permissible when "there is a basis . . . that is not frivolous." 81 The Model Rule is framed in contemplation of an action taken under the control and direction of a client; it is based on the principle that a lawyer should advance claims that his client wants to assert even when they are long shots. ${ }^{82}$

But in a derivative suit, the persons most affected are the corporation and its passive shareholders. Their resources will be consumed by the suit whether it wins or loses. But they do not control and direct the suit. The corporation opposes the

79. Miller v. American Tel. \& Tel. Co., 507 F.2d 759 (3d Cir. 1974) (alleged illegal campaign contribution in failure to sue Democratic National Committee for delinquent telephone account).

80. See Gall v. Exxon Corp., 418 F. Supp. 508 (S.D.N.Y. 1976); Auerbach v. Bennett, 47 N.Y.2d 619 , 393 N.E.2d 994, 419 N.Y.S.2d 920 (1979).

81. Model Rules of Professional Conduct Rule 3.1 (Final Draft 1982), reprinted in 68 A.B.A. J., pullout supplement (Nov. 1982).

82. The Rule's contemplation of client control is revealed in the accompanying comment: "Such action is not frivolous even though the lawyer believes that the client's position ultimately will not prevail. The action is frivolous, however, if the client desires to have the action taken primarily for the purpose of harassing or maliciously injuring a person . . . ." Id. Rule 3.1 comment. 
suit, and the nonsuing shareholders are silent. ${ }^{83}$ Thus, derivative suits should have firmer bases than set forth in the Model Rule.

Attorneys who assert the rights of others, at the others' expense and against or without their will, should have more than a nonfrivolous basis for proceeding. At a minimum, the probability of winning on the law and facts should be substantial. An appropriate measure might be a better-than-even chance of prevailing on the issues and producing a net social benefit. When attorneys subject the assets of involuntary clients to the costs of derivative suits with inadequate bases for believing that the results will be beneficial, they should be assessed some of the costs that they have precipitated.

c. The product of probability times benefit. Mathematical modelers will suggest that a low probability of success should be balanced against a high ratio of benefit to cost in the event of success. ${ }^{84}$ On this supposition, a 1-to-10 chance of succeeding should be multiplied by a 20 -to- 1 ratio of benefit to cost, yielding a benefit probability of 2 to 1 .

This rationalization of forlorn causes should be rejected. In practice, estimates of cost-benefit ratios and of probabilities are crude at best; their inherent inaccuracies should not be aggravated by multiplication. Even if estimates were accurate, application of the norm would mean that nine corporations would be subjected to unsuccessful suits in order that one should reap the big reward. This result is unfair to the constituents of the nine victims of unsuccessful suits.

d. The amounts of assessments. To achieve the objectives of assessments against attorneys, the amounts of assessments should not be determined by a fixed formula. If the judge finds that a suit was unjustified, he should not be obliged to assess the entire defense costs against plaintiffs' attorneys. If obliged to do so, he would probably decide against making any assessment at all. Judges will not saddle erring attorneys with liabilities that would consume their entire incomes for years to come. They will be particularly reluctant when assessments against attorneys are novel and punish conduct that is not condemned by rules of ethics. Judges should be free to impose fractions of defendants' expenses that are sufficient to serve as warnings.

2. Legal Grounds for Assessments Against Attorneys. In a few areas of law other than derivative suits, assessments of defendants' attorneys' fees against plaintiffs' attorneys are firmly established.

a. Express authorization. A source of specific statutory authorization for assessments against attorneys is section 1927 of the Judiciary title of the United States Code. ${ }^{85}$ It authorizes federal courts to require attorneys "to satisfy personally . . .

83. Cf. Dawson, supra note 59 , at 857 .

84. Cf. Joy v. North, 692 F.2d 880, 892 (2d Cir. 1982), cert. denied, 103 S. Ct. 1498 (1983), quoted supra note 12

85. 28 U.S.C. $\S 1927$ (Supp. IV 1980). Before a recent amendment, Pub. L. No. 96-349, § 2, 94 Stat. $1154,1156(1980)$, section 1927 authorized the assessment of taxable costs but not of attorney fees. 
excess costs, expenses, and attorneys' fees" that are caused unreasonably and vexatiously by multiplication of proceedings. 86 One example of "multiplication" was failure to be prepared for trial after agreeing on a date; ${ }^{87}$ another was confusing the evidence by misreading depositions, questioning witnesses on documents that had not been admitted, and interposing meritless objections to interrogations; ${ }^{88}$ a third was a groundless motion to disqualify an opposing attorney. ${ }^{89}$

Another specific authorization for fee assessments against attorneys is found in Rule 37 of the Federal Rules of Civil Procedure, relating to pretrial discovery. Motions to compel answers, failures to respond, and failures to appear may be punished by assessments against parties or against the attorneys who advise the parties when the steps taken were not substantially justified. ${ }^{90}$ The courts have employed the provision to assess expenses and fees against attorneys in a number of cases involving flagrant and repeated failures to comply with proper discovery procedures. ${ }^{91}$ The rule has no application to attorney misconduct in other settings.

The newest addition to express judicial authority for assessing fees against attorneys is a 1983 amendment to Rule 11 of the Federal Rules of Civil Procedure. ${ }^{92}$ The Rule makes attorneys guarantors of reasonable bases for the pleadings they file. The amendment reinforces the rule both with respect to its substantive requirements and the sanctions for its enforcement. With respect to substance, the former requirement of belief in "good ground to support" the pleading is amplified to require belief "formed after reasonable inquiry [that the pleading] is well grounded in fact and is warranted by existing law or a good faith argument for the extension, modification, or reversal of existing law. . . ." With respect to sanctions, the former authorization of "appropriate disciplinary action" has been expanded to cover "an appropriate sanction, which may include an order to pay to the other party or parties the amount of the reasonable expenses incurred because of the filing ...." The amendments codify the holding of a reported decision under the old rule which assessed expenses against an attorney who filed in a federal court a claim over which the court clearly had no jurisdiction. ${ }^{93}$

b. Implied authorization. An implication of authority to make assessments against attorneys has been found in a federal appellate rule expressly allowing awards of damages to parties against whom frivolous appeals have been filed. ${ }^{94}$ The rule does not say who shall be assessed for the award, but the courts have

Roadway Express v. Piper, 447 U.S. 752, 757-63 (1980). For a review of cases under the section before the amendment, see Comment, supra note 75 , at 623-29.

86. 28 U.S.C. $\S 1927$.

87. Bardin v. Mondon, 298 F.2d 235 (2d Cir. 1961).

88. Kiefel v. Las Vegas Hacienda, Inc., 404 F.2d 1163 (7th Cir. 1968), cert. denied, 395 U.S. 908 (1969).

89. North Am. Foreign Trading Corp. v. Zale Corp., 83 F.R.D. 293 (S.D.N.Y. 1979).

90. FED. R. Civ. P. 37(a)(4).

91. Cases are collected and reviewed in Comment, supra note 75, at 629-33.

92. FED. R. CIV. P. 11 (as amended Apr. 28, 1983, 51 U.S.L.W. 4501).

93. Textor v. Board of Regents, 87 F.R.D. 751 (N.D. Ill. 1980).

94. FED. R. APP. P. 38. 
determined that attorneys, as well as parties, are subject to assessments. ${ }^{95}$

However, a statutory authorization to assess attorneys' fees against parties does not ordinarily imply authorization to assess them against opposing attorneys. The argument for this implication was firmly rejected by the Supreme Court in the 1980 decision of Roadway Express $v$. Piper. ${ }^{96}$ Piper sued under civil rights provisions which authorized assessment of the winner's attorneys' fees against the loser. ${ }^{97}$ When Piper's claim was found to be without basis, Roadway moved for an assessment against Piper's attorneys. The Court rejected the civil rights acts as bases of assessment against attorneys, ${ }^{98}$ although it found another basis in the fundamental powers of courts. ${ }^{99}$

c. Inherent power of courts. The Supreme Court in Roadway Express v. Piper announced the inherent right of a court to assess expenses (including attorneys' fees) of one party against the attorneys for the other party as a facet of a court's powers of discipline over the attorneys practicing before it. ${ }^{100}$ The occasion for such an assessment is the filing of a suit or motion "in bad faith."101 The Court in Roadway, without analyzing the meaning of the term remanded the case to the district court for a determination of whether the attorneys acted "in bad faith." 102 The lower court had found that the plaintiffs' attorneys had filed a class suit rather than an individual one without the knowledge of their clients and had inadequately prosecuted the suit, being guilty of deliberate inaction. ${ }^{103}$ These acts, however, were not necessarily proof of bad faith. ${ }^{104}$

3. The Need for New Law. Assessments against attorneys on the grounds presently recognized do not effectively deter useless derivative suits. Some of the grounds are narrowly confined to particular procedures-discovery and appeals. Others have generally been confined to particular procedures within a suitmotions, responses, and appearances-rather than to suits themselves. In a rare case in which the filing of the suit itself was found to be abusive, there was a total lack of jurisdiction rather than an unsupported theory or a lack of evidence. ${ }^{105}$ Finally, even the Roadway standard of "in bad faith" effects little deterrence, since the standard for bad faith is often very subjective.

Effective control of derivative suits by assessments against attorneys will require a more demanding standard for the suits. Not only must they be in good

95. See, e.g., United States v. Potamkin Cadillac Corp., 689 F.2d 379 (2d Cir. 1982).

96. 447 U.S. 752 (1980). The statute involved in Roadway was promptly amended to authorize assessments of attorney fees, see supra note 85 , but the ruling against automatic inclusion of attorney fees within "costs" remains presumably valid with respect to other statutes.

97. 42 U.S.C. $\S \S 1988,2000 \mathrm{e}-5(\mathrm{k})$ (1976 \& Supp. IV 1980).

98. 447 U.S. at $757-63(1980)$.

99. Id. at 764-67.

100. Id.

101. Id. at 766 .

102. Id.; of. Ryan, supra note 75 , at $136-37$. 1977))

103. 447 U.S. 752, 755-56 (citing Monk v. Roadway Express, 73 F.R.D. $411,414,417$ (W.D. La.

104. Id. at 767 .

105. Textor v. Board of Regents, 87 F.R.D. 751 (N.D. Ill. 1980). 
faith and with basis, but they must have a reasonable chance of producing a net benefit.

This standard is unlikely to evolve by judicial decision. Case law on abusive litigation is concerned primarily with what a lawyer may permissibly do to carry out a client's wishes. To articulate a radically different standard for derivative suits would require a leap too long for judicial tradition.

Neither Congress nor a state legislature is likely to adopt legislation that would impose a heavier responsibility on attorneys filing derivative suits. Although there are pressure groups who are interested in legislation to control derivative suits, none of them is likely to opt for this type of solution.

The most conspicuous wave of legislation against derivative suits, which blossomed in the security-for-expenses statutes of the 1940's, was instigated by the New York Chamber of Commerce. ${ }^{106}$ As we have seen, the legislation that the Chamber supported was not valuable in separating the meritorious from the meritless suits; rather, it sought to impose forbidding burdens on the large majority of shareholders. The Chamber of Commerce would be unlikely to favor legislation that would deter only the small fraction of suits that have minimal grounds.

A second group that has had a major influence on corporation laws is the Committee on Corporate Laws of the Section of Corporation, Banking and Business Law of the American Bar Association. It has drafted a widely copied model act, which requires contemporaneous ownership and which for many years authorized orders to post security for expenses. ${ }^{107}$ The recent proposal to eliminate the provision on security for expenses ${ }^{108}$ indicates that the Corporate Laws Committee is now reasonably neutral on derivative suits. The Committee's membership includes some lawyers who frequently file derivative suits as well as lawyers who defend against them. This membership is unlikely to unite in putting the burden of controlling derivative suits on plaintiffs' lawyers. If it did, it would encounter the opposition of other bar association committees.

A third group that has turned its attention to the regulation of derivative suits is the American Law Institute (ALI) in its Principles of Corporate Governance and Structure. ${ }^{109}$ Its 1982 draft of rules for derivative suits contains a number of devices that are designed to separate the productive from the wasteful. It renounces security for expenses 110 and palliates the contemporary ownership rule. ${ }^{111}$ It refines the measures to be used in awarding fees to plaintiffs' attorneys ${ }^{112}$ and in dismissing suits on motion of independent directors. ${ }^{113}$ Most significantly for the present con-

106. House, supra note 5.

107. Model Business Corp. ACt $\S 49$ (1979).

108. Committee on Corporate Laws, Section of Corporation, Banking and Business Law of the American Bar Association, Proposed Revisions of the Model Business Corporation Act Affecting Actions by Shareholders, 37 Bus. LAW. 261, 265-66 (1981).

109. Principles of Corporate Governance and Structure: Restatement and RecommenDATIONS $\S \S 701-707$ (Tent. Draft No. 1, 1982) [hereinafter cited as Principles]. For a detailed critique of this draft, see Cox, supra note 5, at 994-1007.

110. PRINCIPLES, supra note $109, \S 7.02(\mathrm{~d})$.

111. Id. $\S 7.02(\mathrm{a})$.

112. Id. $\$ 7.07(\mathrm{a})$

113. Id. $\$ 7.03$. 
text, it expressly authorizes assessments against attorneys on either side (as well as against parties) for proceedings "in bad faith or without reasonable cause." 114 But attorneys are not made responsible for estimates of the cost-benefit balance; this is to be considered only by directors in deciding whether to move to dismiss a suit. ${ }^{115}$ At this writing, the final content of the ALI principles cannot be foreseen. The draft appears to have encountered substantial internal resistance. ${ }^{116}$

In federal courts, nonmeritorious suits are likely to be warded off by the recent amendment of Rule 11.117 A rigorous application of the rule to derivative suits would fit with the Court's demonstrated coolness toward class actions ${ }^{118}$ and the Chief Justice's concern with diminishing the caseloads of federal courts. ${ }^{119}$ However, federal restrictions alone are likely to have very little effect on the aggregate burden that derivative suits impose on corporations. If the federal restrictions are not matched by state rules, the cases will merely move from federal to state courts.

State courts are less willing to exclude suitors. This tendency exists partly because they, unlike federal courts, cannot readily dismiss suits with the thought that the claims can be brought in other courts. State courts are themselves the "other courts." Furthermore, state judges are commonly less antipathetic than are federal judges to the litigation explosion. This is probably because their shorter tenure and elective positions make them more responsive to the demands of the organized bar and of the mass of voters.

Some states already have court rules or civil procedure statutes that authorize assessments against attorneys for violations of rules ${ }^{120}$ or for conducting vexatious litigation, ${ }^{121}$ and at least one state makes assessments for misconduct under the court's inherent power to discipline attorneys. ${ }^{122}$ As in the federal courts, an enlarged conception of the scope of these sanctions would be required to use them as winnowers of shareholders' derivative suits.

114. Id. $\S 7.02$ (e)(ii). This and other provisions of the draft were foreshadowed by Professors Coffee \& Schwartz, supra note 3 , at 334 .

115. PRINCIPLES, supra note $109, \S 7.03$.

116. This resistance may be inferred from the remarks of Roswell B. Perkins, Background and Status of ALI Corporale Covernance Project, made at a forum of the New York City Bar Association (Mar. 14, 1983) (reproduced and circulated to ALI members in a memorandum dated April 5, 1983). The drafting committee made no presentation at the 1983 ALI annual meeting, although earlier plans had contemplated submission of a draft on that occasion.

117. See supra note 92 and accompanying text.

118. A series of decisions has added impediments to direct class actions. See Eisen v. Carlisle \& Jacquelin, 417 U.S. 156 (1974) (class plaintiff must bear the expense of notifying other class members); Snyder v. Harris, 394 U.S. 332 (1969) (no aggregation of separate and distinct claims to meet the federal jurisdictional threshold). "Frankenstein monster" was the term applied by one federal judge to a particular class action, Eisen v. Carlisle \& Jacquelin, 391 F.2d 555, 572 (2d Cir. 1968) (Lumbard, C.J., dissenting), rev'd, 417 U.S. 156 (1974), and by another to Rule 23 of the Federal Rules of Civil Procedure, which regulates class actions. San Antonio Tel. Co. v. American Tel. \& Tel. Co., 68 F.R.D. 435, 436 (W.D. Tex. 1975).

119. See, e.g., Warren, Address, 46 A.L.I. Proc. 2 (1969).

120. See, e.g., Alaska R. CrV. P. 37 (discovery sanctions); OR. R. Crv. P. 46B(3) (discovery sanctions); Wash. Disciplinary R. ATtYys. 7.1.

121. See CAL. R. CT. 26(a) (frivolous appeals).

122. Gottlieb v. Edelstein, 84 Misc. 2d 1053, 375 N.Y.S.2d 532 (Sup. Ct. 1975). 


\section{After THOUGHTS}

The analysis in the foregoing pages suggests that the devices that are currently most used for controlling derivative suits are inefficient. They are likely to deter or defeat meritorious suits while they fail to exclude suits that are maintained for harassment. Courts could winnow better if they would abandon the devices of security for expenses, contemporaneous ownership, and dismissal on motion of independent directors and would rely instead on assessments against plaintiffs' attorneys.

The reader's response to this contention will probably depend less on the credibility of the analysis presented than on preferences which the article has not articulated. The choice is basically between controlling unproductive activities of business managers by judicial intervention or leaving these activities to the regime of organizational autonomy. Under one model, judicial intervention is relied on to restrain abuses of power by executives and abuses of process by plaintiffs' attorneys. Under the other, executives are insulated against judicial intervention in all but the most flagrant cases, and abuses of process are deterred by the remoteness of a complainant's chance of winning.

Which model one prefers will depend in large part on how well one thinks the corporate world operates without intervention. Some people believe that the corporate world operates well enough with very little intervention; others see a need to increase the pressure for higher standards of management.

The choice will depend also on how confident one is that judges and juries will reach the right answers. If courts are likely to assess liabilities against the wrong managers or assess expenses against the wrong attorneys, more harm than good may be done by giving them the power to do so.

At stake is not only the profitability of equity investments, or even the efficiency of business enterprises, but the credibility of business management. If managers are perceived as ripping off their shareholders with impunity, they will be suspected of acting with even less regard for employees, customers, and neighbors; pervasive regulation will continue its creeping conquest. If the legal system is seen as enforcing integrity at the managerial level, a modicum of freedom in enterprise will have a better chance of surviving. 